\title{
ANALISIS KOMPARASI WIRELESS NETWORK PADA SIMULASI AIRLINK UBIQUITI DENGAN REAL HADWARE UBIQUITI
}

\author{
Ahmad Tantoni ${ }^{1}$, Mohammad Taufan Asri Zaen ${ }^{2}$ \\ ${ }^{1}$ Teknik Informatika, STMIK Lombok \\ ${ }^{2}$ Sistem Informasi, STMIK Lombok \\ Jln. Basuki Rahmat No.105 Praya Lombok Tengah 83511 \\ ${ }_{1}^{1}$ ahmad.tantoni@students.amikom.ac.id, ${ }^{2}$ opanzain@gmail.com
}

\begin{abstract}
In conducting PtP or PtMP wireless signals, a simulation is needed with a design to determine the height of the tower and see the height of the surrounding buildings from the Access Point (site A) and Station (site B) to avoid the Line of Sight (LOS) and Fresnel Zone. Not only that, in designing the rt/rw.net network, it is also necessary to select devices and network simulation in order to estimate the results of the desired network performance and how much it costs. Problems occur when the network hardware has been installed and pointed from Site A to Site B to get unsatisfactory results according to previous simulations.

This study is to determine the accuracy of the results of the ubiquiti simulation performance with the real hardware network Ubiquitous products. This is done because when sometimes simulateds, the expected results do not match the real estate. The research methodology used by PPDIOO Method is made by Cisco.

Research at Brembuk.net Pancor, East Lombok with comparative analysis of wireless networks using simulation airlink.com ubiquiti and real hardware network ubiquitous products, carried out from site $A$ to site $B$ with a distance of approximately 1.47 kilometers. From the $R X$ signal strength in the simulation is better than when using real hardware because the simulation produces a signal of $-37.80 \mathrm{dBm}$ while in the real hardware produces the signal $-41.00 \mathrm{dBm}$. The total capacity of download \& upload in real hardware is better than when using simulation because in real hardware it produces 137.54 Mbps while in simulation it produces 121.10 Mbps performance, and between airlink.ubnt.com using ubiquiti simulation and real hardware network ubiquiti products almost get the same results.
\end{abstract}

Keywords: performance, wireless network, ubiquiti, airlink, PPDIOO

\begin{abstract}
Abstrak
Dalam melakukan PtP atau PtMP sinyal wireless diperlukan simulasi dengan perancangan untuk menentukan berapa ketinggian tower dan melihat ketinggian bangunan disekitar dari Access Point (site A) dan Station (site B) supaya terhindar dari Line of Sight (LOS) dan Fresnel Zone. Tidak hanya itu saja dalam merancang jaringan rt/rw.net juga diperlukan pemilihan perangkat dan simulasi jaringan agar bisa memperkirakan hasil performa jaringan yang diinginkan dan berapa biaya yang dikeluarkan. Permasalahan terjadi pada saat hardware jaringan sudah pasang dan di pointing dari Site A ke Site B mendapatkan hasil yang tidak memuaskan sesuai simulasi yang sudah dilakukan sebelumnya.

Penelitian ini untuk mengetahui tingkat keakuratan hasil performa simulasi ubiquiti dengan real hardware jaringan produk ubiquiti. Hal ini dilakukan karena pada saat disimulasi kadang hasil yang di harapkan tidak sesuai dengan real dilapangan. Metodologi penelitian yang digunakan PPDIOO Method yang dibuat oleh Cisco.

Penelitian di Brembuk.net Pancor, Lombok Timur dengan analisis perbandingan jaringan wireless menggunakan simulasi airlink.com ubiquiti dan real hadware jaringan produk ubiquiti, dilakukan dari site A ke site B dengan jarak kurang lebih 1.47 kilometer. Dari RX sinyal strength pada simulasi lebih bagus dari pada saat menggunakan real hardware karena pada simulasi menghasilkan sinyal $-37.80 \mathrm{dBm}$ sedangkan pada real hardware menghasilkan sinyal $-41.00 \mathrm{dBm}$. Total capacity download \& upload pada real hardware lebih bagus dari pada saat menggunakan simulasi karena pada real hardware menghasilkan performa 137.54 Mbps sedangkan pada simulasi menghasilkan performa 121.10 Mbps, serta antara penggunaan simulasi ubiquiti airlink.ubnt.com dengan real hardware jaringan produk ubiquiti mendapatkan hasil yang hampir sama.
\end{abstract}

Kata kunci: performa, jaringan wireless, ubiquiti, airlink, PPDIOO

ISSN. 2620-6900 (Online) 2620-6897 (Cetak) 


\section{Pendahuluan}

Perkembangan teknologi informasi akhir ini sangat berkembang, terlebih lagi pada bidang konsentrasi ilmu jaringan komputer. Salah satu dari perkembangan jaringan komputer terbentuknya rt/rw.net. rt/rw.net merupakan jasa layanan internet yang murah di kalangan masyarakat. Dalam merancang rt/rt.net diperlukan teknik pointing untuk menyebarkan sinyal wireless ke berbagai lokasi dimana teknik pointing dibagi menjadi dua yaitu point to point (PtP) dan point to multipoint (PtMP).

Dalam melakukan PtP atau PtMP sinyal wireless diperlukan simulasi dengan perancangan untuk menentukan berapa ketinggian tower dan melihat ketinggian bangunan disekitar dari Access Point (site A) dan Station (site B) supaya terhindar dari Line of Sight (LOS) dan Fresnel Zone. Tidak hanya itu saja dalam merancang jaringan rt/rt.net juga diperlukan pemilihan perangkat dan simulasi jaringan agar bisa memperkirakan hasil performa jaringan yang diinginkan dan berapa biaya yang dikeluarkan. Para praktisi networking sering menjadikan ini sebagai acuan penentuan pemeilihan alat dan performa jaringan yang diinginkan. Permasalahan terjadi pada saat hardware jaringan sudah pasang dan di pointing dari Site A ke Site B mendapatkan hasil yang tidak memuaskan yang sesuai simulasi yang sudah dilakukan sebelumnya. Maka dari itu penelitian ini ingin menguji apakah rancangan ketika melakukan simulasi dan pemasangan hardware jaringan wireless mendapatkan hasil yang sama atau berbeda. Penelitian ini berfokus pada simulasi yang ada pada airlink.ubnt.com dan hardware ubiquiti, dan untuk mengetahui tingkat keakuratan hasil performa simulasi ubiquiti dengan real hardware jaringan produk ubiquiti.

\section{Tinjuan Pustaka}

Penelitian yang dilakukan oleh Duskarnaen dan Nurfalah dengan judul Analisis, Perancangan, Dan Implementasi Jaringan Wireless Point to Point Antara Kampus A dan Kampus B Universitas Negeri Jakarta. Persamaan penelitian ini sama-sama melakukan PtP dari Side A ke Side B. Perbedaan penelitian ini tidak melakukan analisis perbandingan antara saat simulasi dengan saat implementasi jaringan wireless.

Penelitian yang dilakukan oleh Setyawan dengan judul Membangun Jaringan Wireless
Berbasis Router Mikrotik Dengan Menggunakan Point to Multi Point (PTM) Pada PT. Telkom Pekalongan Provinsi Jawa Tengah. Persamaan penelitian ini menggunakan transmisi wireless untuk menyebarkan jaringan internet. Perbedaan penelitian ini melakukan PtMP sinyal wireless dan tidak melakukan analisis perbandingan antara saat simulasi dengan saat implementasi jaringan wireless.

Penelitian yang dilakukan oleh Pranoto dan Priadi dengan judul Desain dan Implementasi Wireless LAN Berdasarkan Perhitungan Link Budget DAN Throughput (Studi Kasus BBS UnilaNet Tiga Satu Mandiri Prima). Persamaan penelitian ini sama-sama melakukan PtP dari Side A ke Side B dan melakukan pertimbangan Line Of Sight (LOS). Perbedaan penelitian ini tidak melakukan analisis perbandingan antara saat simulasi dengan saat implementasi jaringan wireless.

\subsection{Teknologi informasi}

Teknologi ini merupakan pengembangan dari teknologi komputer yang dipadukan dengan teknologi telekomunikasi. Definisi kata 'informasi' sendiri secara internasional telah disepakati sebagai 'hasil dari pengolahan data' yang secara prinsip memiliki nilai atau value yang lebih dibandingkan dengan data mentah. Komputer merupakan bentuk teknologi informasi pertama (cikal bakal) yang dapat melakukan proses pengolahan data menjadi informasi. Dalam kurun waktu yang kurang lebih sama, kemajuan teknologi telekomunikasi terlihat sedemikian pesatnya, sehingga telah mampu membuat dunia menjadi terasa lebih kecil ( mereduksi ruang dan waktu = time and space) . Dari sejarah ini dapat disimpulkan bahwa yang dimaksud dengan teknologi informasi adalah suatu teknologi yang berhubungan dengan pengolahan data menjadi informasi dan proses penyaluran data/informasi tersebut dalam batasbatas ruang dan waktu. Dengan berpegang pada definisi ini, terlihat bahwa komputer hanya merupakan salah satu produk dalam domain teknologi informasi. (Indrajit,. 2000)

\subsection{Jaringan Komputer}

Jaringan komputer adalah himpunan "interkoneksi" antara 2 komputer autonomous atau lebih yang terhubung dengan media transmisi kabel atau tanpa kabel (wireless). (Syafrizal, 2005) 


\subsection{Line of Sight (LOS) dan Fresnel Zone}

Sistem komunikasi radio memerlukan syarat kondisi LOS yang benar-benar terbuka. Pada propagasi LOS terdapat daerah yang harus dan wajib terhindar dari halangan (obstacle), daerah itu disebut fresnel zone.

Fresnel Zone adalah sebuah daerah interferensi yang dapat bersifat konstruktif maupun destruktif yang tercipta ketika propagasi gelombang elektromagnetik di ruang bebas mengalami pantulan (multipath) atau difraksi. Fresnel Zone harus betul-betul bebas dari halangan. (Suji, 2013)

\section{$2.4 \mathrm{rt} / \mathrm{rw} . n e t$}

Istilah RT/RW-net pertama kali digunakan sekitar tahun 1996-an oleh para mahasiswa di Universitas Muhammadyah Malang (UMM), seperti Nasar, Muji yang menyambungkan koskos-an mereka ke kampus UMM yang tersambung ke jaringan AI3 Indonesia melalui GlobalNet di Malang dengan gateway Internet di ITB. Sambungan antara RT/RW-net di kos-kosan ke UMM dilakukan menggunakan walkie talkie di VHF band 2 meter pada kecepatan 1200bps. Kemudian para mahasiswa Malang ini menamakan jaringan mereka sebagai RT/RW-net karena memang di sambungkan ke beberapa rumah disekitar kos-kosan mereka. (Mikrotik,2018)

\subsection{Pointing to Point}

Point to point merupakan kondisi sambungan lansung dimana terdapat dua node yang saling terhubung tanpa perantara atau tanpa melibatkan node lain seperti ditunjukkan gambar 1.

Jaringan point to point dapat menghubung dua jalur LAN melalui mode bridge tanpa melalui proses routing. Antena jenis directional merupakan antena yang cocok untuk pemasangan point to point karena memiliki pancaran yang lurus dan tidak menyebar. (Anwar, 2007)

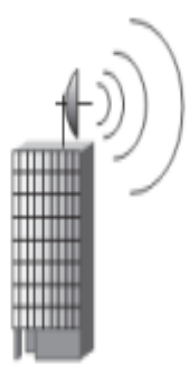

LANI

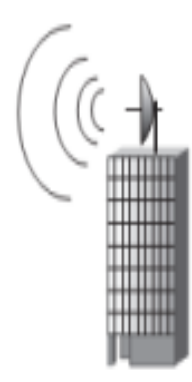

LAN2

\section{Metodologi Penelitian}

\section{Gambar 2.1. Point to Point}

Metodologi penelitian yang digunakan adalah PPDIOO Method. Penjelasan dari masingmasing tahapan PPDIOO (Teare, 2008), sebagai berikut:

a. Prepare (Persiapan). Melibatkan penerapan persyaratan organisasi (bisnis), mengembangkan startegi jaringan, mengusulkan arsitektur jaringan konseptual tingkat tinggi dan mengindentifikasi teknologi terbaik yang dapat mendukung arsitektur jaringan.

b. Plan (Rencanakan). Melibatkan identifikasi kebutuhan jaringan awal berdasarkan tujuan, fasilitas, kebutuhan pengguna, kebutuhan hardware/software dan sebagainya. Tahap rencana melibatkan karakteristik situs dan menilai jaringan yang ada dan melakukan analisis untuk menentukan apakah infrastruktur yang ada sistem dan lingkungan operasional dapat mendukung sistem yang diusulkan.

c. Design (Perancangan). Persyaratan awal yang tentukan dalam tahapan perencanaan mendorong kegiatan spesialis desain jaringan. Spesifikasi desain jaringan yang dihasilkan adalah desain rinci komprehensif yang memenuhi kebutuhan bisnis saat ini dan kebutuhan teknis lalu menggabungkan spesifikasi untuk mendukung ketersediaan, keandalan, keamanan, skalabilitas dan kinerja.

d. Implement (Pelaksanaan). Jaringan yang dibangun atau komponen tambahan lainnya dimasukkan sesuai dengan spesifikasi desain dengan tujuan mengintegrasikan perangkat tanpa menggangu jaringan yang ada atau membuat titik kerentanan.

e. Operate (Pengoperasian \& Evaluasi). Merupakan tujuan akhir dari kesesuaian desain yang sudah rancang. Tahapan operasional melibatkan pemeliharaan/menjaga jaringan komputer melalui kegiatan pada setiap harinya, 
termasuk menjaga ketersediaan jaringan yang tinggi dan mengurangi biaya.

f. Optimize. Melibatkan manajemen jaringan yang proaktif. Tujuan dari manajemen proaktif adalah untuk mengidentifikasi dan menyelesaikan masalah sebelum masalah nyata muncul dan dapat mempengaruhi organisasi. Deteksi dan koreksi kesalahan relatif (troubleshooting) dibutuhkan ketika manajemen proaktif tidak dapat memprediksi dan mengurangi kegagalan.

\section{Hasil dan Pembahasan}

Pengujian dilakukan dengan simulasi aplikasi berbasis website airlink.ubnt.com ubiquiti dengan menampilkan data pendukung screenshot dan akan dibandingkan dengan data pendukung screenshot setelah implementasi jaringan wireless.

\subsection{Pengujian Simulasi Ubiquiti}

Studi kasus dilakukan di Brembuk.net Pancor, dan hasil dari screenshot simulasi airlink.ubnt.com sebagai berikut:

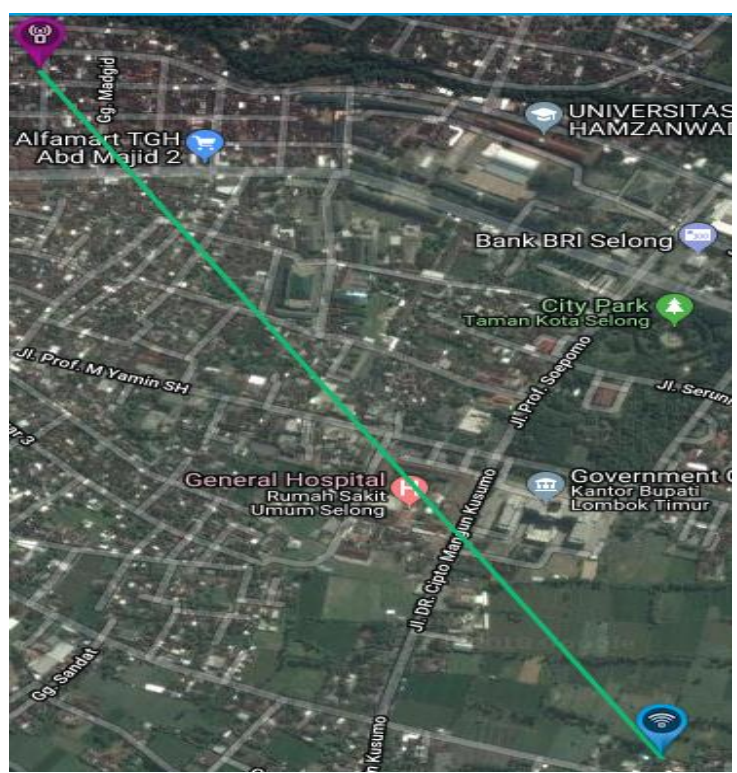

Gambar 4.1. Simulasi Link PtP (Source: airlink.ubnt.com)

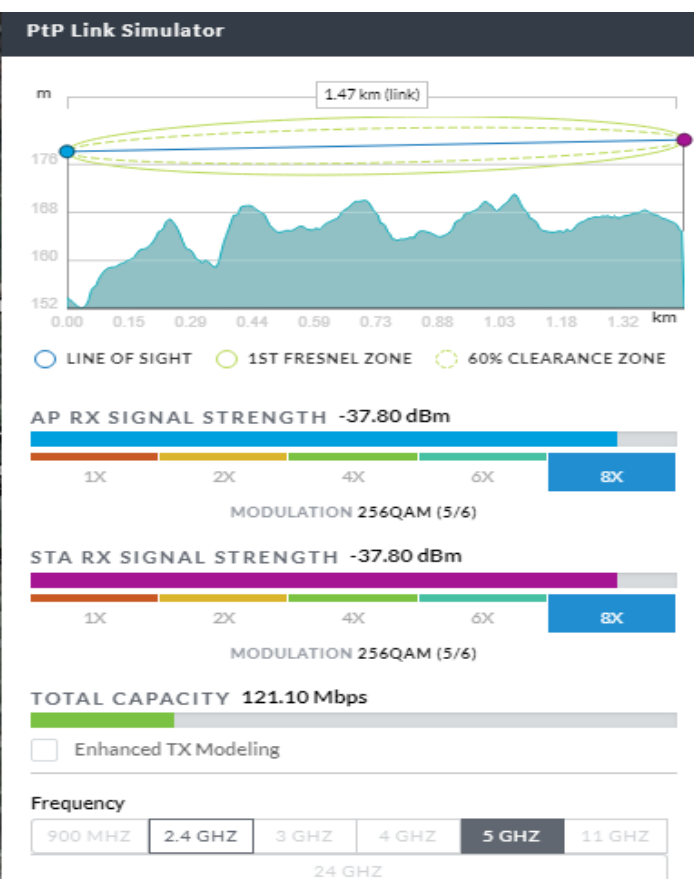

\section{Gambar 4.2. Simulasi Link PtP}

(Source: airlink.ubnt.com)

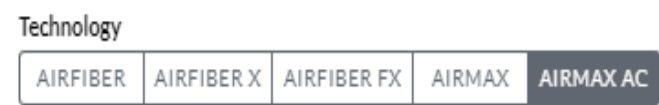

Channel Width

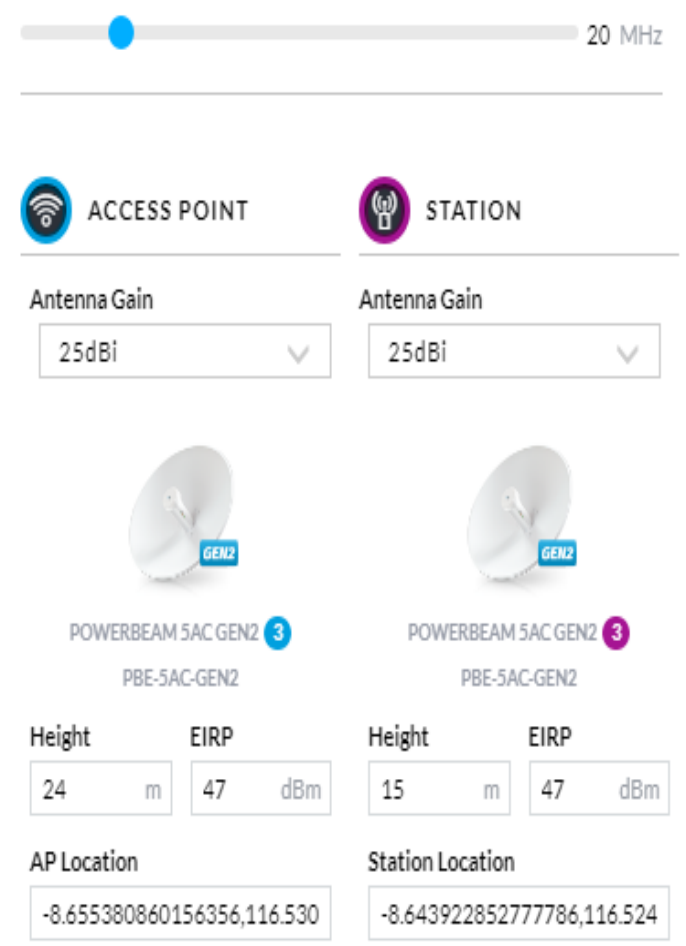

C Copyright 2006-2018 Ubiquiti Networks, Inc

Gambar 4.3 Simulasi Link PtP

ISSN. 2620-6900 (Online) 2620-6897 (Cetak) 


\section{(Source: airlink.ubnt.com)}

Gambar 2 menunjukan simulasi jaringan point to point dari Site A sebagai AccessPoint dengan tanda berwarna biru ke Site B sebagai Station dengan tanda berwarna ungu, sedangkan gambar 3 dan gambar 4 menunjukan hasil rekomendasi dari simulasi jaringan.

Dari gambar 3 menunjukan tidak ada penghalang dari gedung dan bebas dari Line of Sight (LOS) dan Fresnel Zone.

Jarak antara Site A dan Site B adalah 1.47 $\mathrm{Km}$, dengan RX sinyal strength, total capacity, frequency, tecnology, channel width, hardware, ketinggian tower ada pada tabel 1 sebagai berikut:

Tabel 1. Simulasi Link PtP

\begin{tabular}{|c|c|c|}
\hline & $\begin{array}{l}\text { AccessPoint (AP) } \\
\text { Site A }\end{array}$ & $\begin{array}{l}\text { Station (STA) } \\
\text { Site B }\end{array}$ \\
\hline $\begin{array}{l}\text { RX Sinyal } \\
\text { Strength }\end{array}$ & $-37.80 \mathrm{dBm}$ & $-37.80 \mathrm{dBm}$ \\
\hline $\begin{array}{l}\text { Total } \\
\text { Capacity } \\
\text { Bandwidth } \\
\text { Download \& } \\
\text { Upload }\end{array}$ & 121.10 Mbps & 121.10 Mbps \\
\hline Frequency & $5 \mathrm{Ghz}$ & $5 \mathrm{Ghz}$ \\
\hline Tecnology & AirMAX AC & AirMAX AC \\
\hline $\begin{array}{l}\text { Channel } \\
\text { Width }\end{array}$ & $20 \mathrm{Mhz}$ & $20 \mathrm{Mhz}$ \\
\hline Hardware & PBE-5AC-Gen2 & PBE-5AC-Gen2 \\
\hline $\begin{array}{l}\text { Ketinggian } \\
\text { Tower } \\
\end{array}$ & 24 Meter & 15 Meter \\
\hline
\end{tabular}

\subsection{Pengujian Real Hardware Ubiquiti}

Hasil dari screenshot dan dokumentasi foto impelentasi simulasi airlink.ubnt.com sebagai berikut:

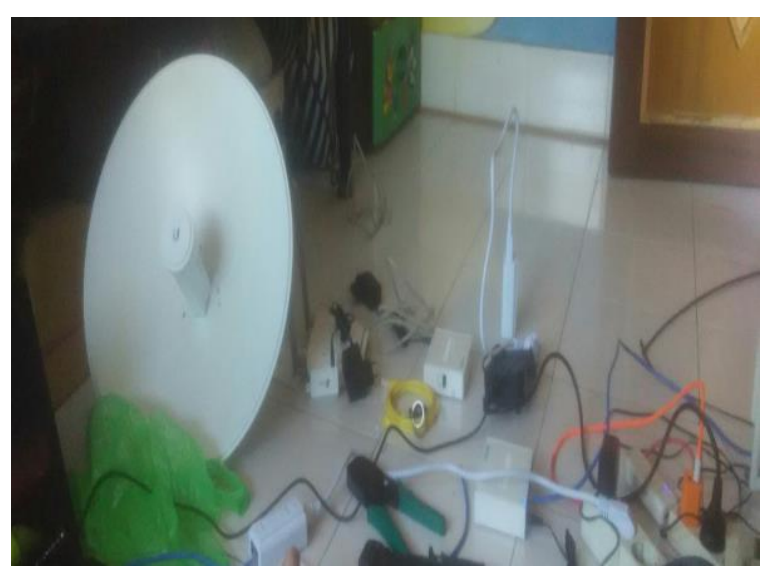

ISSN. 2620-6900 (Online) 2620-6897 (Cetak)

\section{Gambar 4.4. Hardware Jaringan}

Gambar 5 menunjukan hardware jaringan wireless yang digunakan adalah PBE-5AC-Gen2 atau PowerBeam M5AC Gen2 dengan spesifikasi frequency $5 \mathrm{GHz}$, throughput, $450+\mathrm{Mbps}$, range $25+\mathrm{km}$, management radio Yes

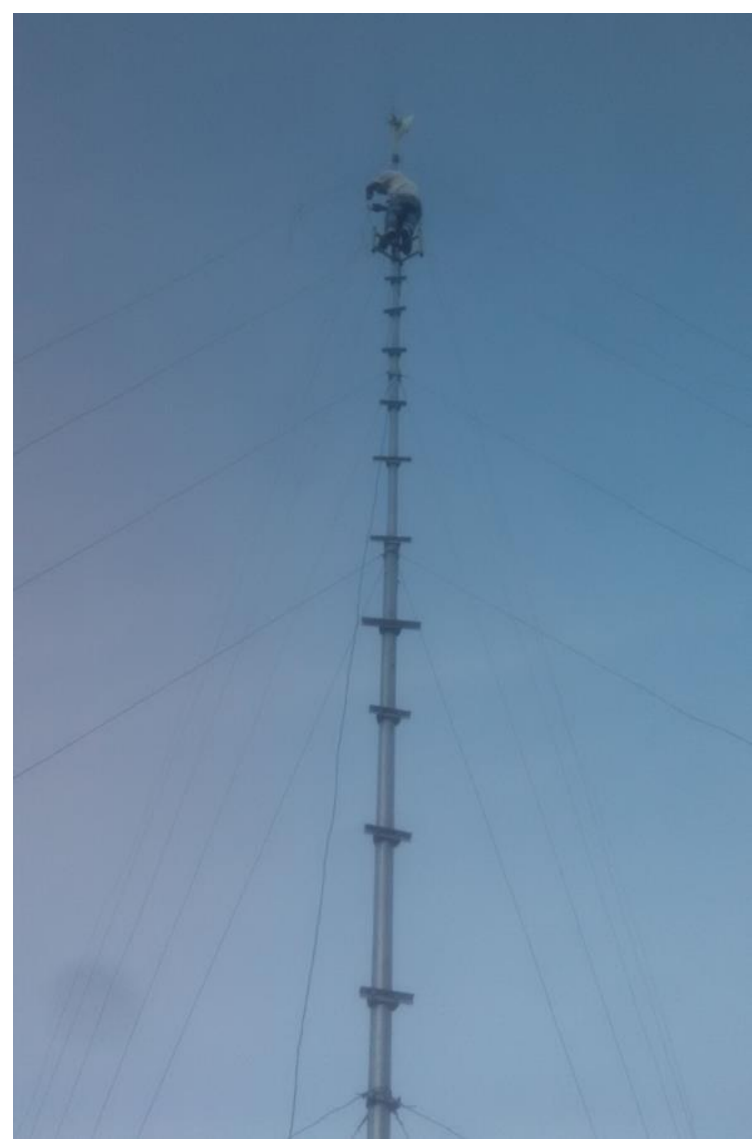

\section{Gambar 4.5. Pemasangan Tower dan Hardware Jaringan}

Gambar 6. Menunjukan pemasangan hardware jaringan wireless $\mathrm{PBE}-5 \mathrm{AC}-\mathrm{Gen} 2$ pada BTS site B

\subsection{Hasil Pengujian}

Setelah pemasangan instalasi jaringan wireless di Site A dan Site B dengan menggunakan rekomendasi simulasi airlink.ubnt.com mendapatkan hasil RX sinyal strength, total capacity download dan upload, frequency, technology, channel width sebagai berikut:

\section{a. RX Sinyal Strength}

Hasil RX sinyal strength pada saat instalasi jaringan wireless ditunjukkan pada gambar $7 \mathrm{di}$ 
bawah ini. Gambar 7 menunjukan RX sinyal strength $-40 \mathrm{dBm}$ sampai $-41 \mathrm{dBm}$.

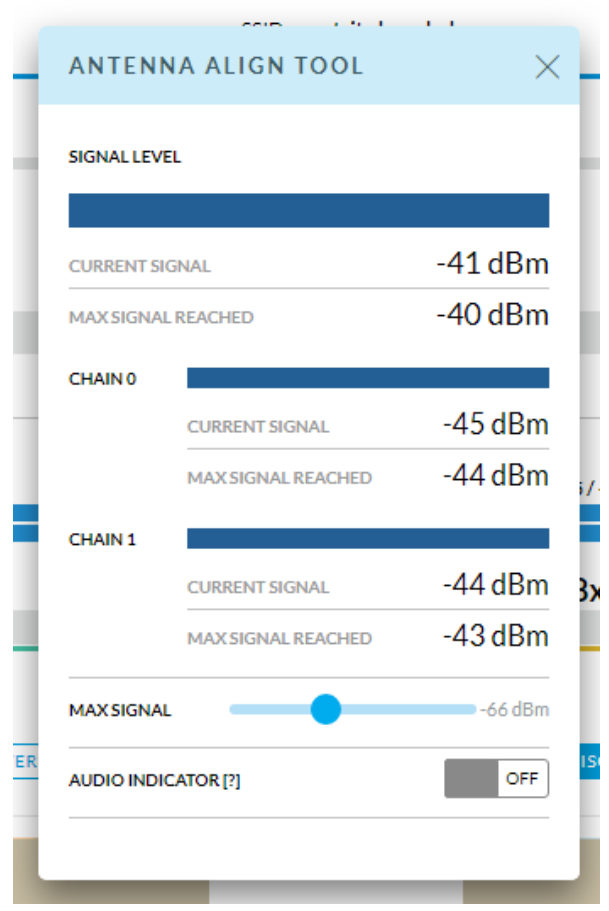

\section{Gambar 4.6. Real Hardware PtP RX Sinyal Strength}

\section{b. Total Capacity Download dan Upload}

Pengujian download dan upload mendapatkan hasil sebagai berikut:

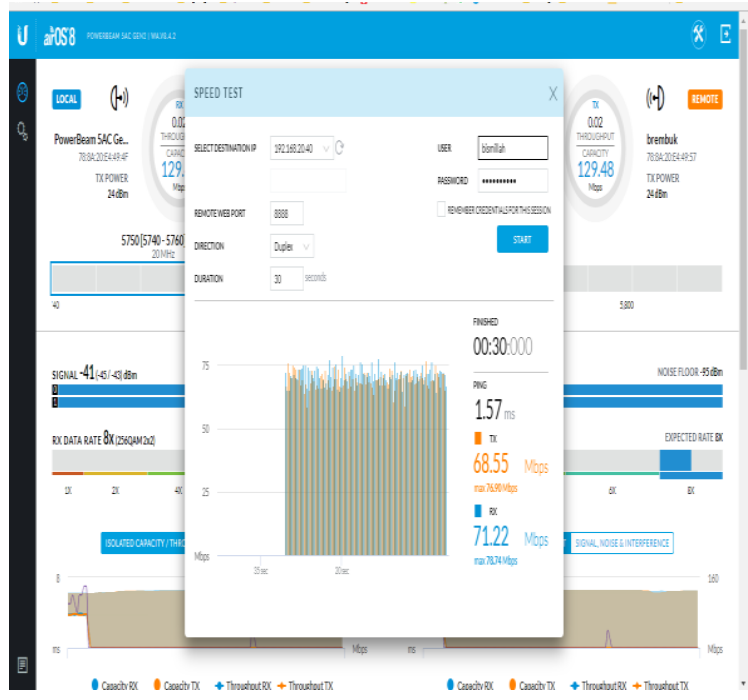

Gambar 4.7. Real Hardware PtP untuk Download dan Upload

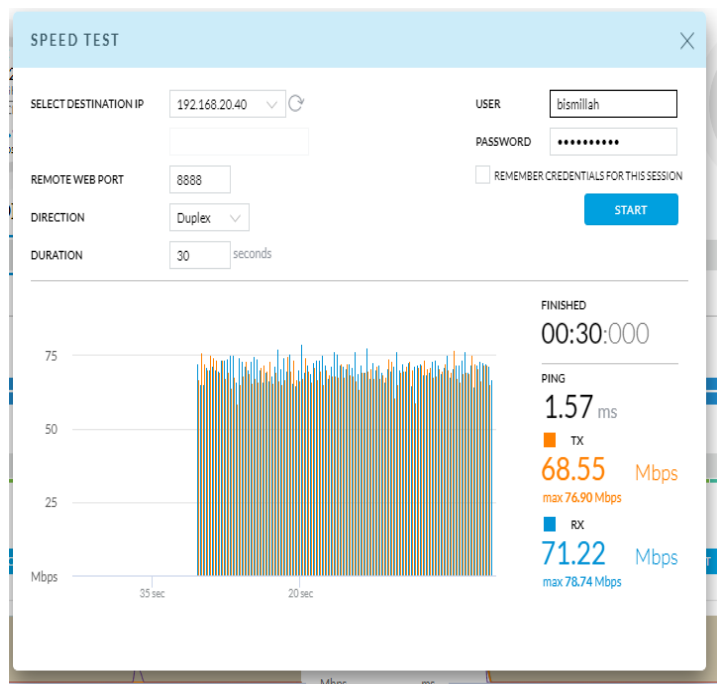

\section{Gambar 4.8. Speed Test untuk Download dan Upload}

Gambar 8 dan gambar 9 menunjukan hasil nge-ping, download dan upload dari Access Point ke Station secara bersamaan. Dilakukan dengan 30 kali pengujian dan diperoleh hasil rata-rata nge-ping sebesar 1,57 ms, download sebesar 68,55 Mbps, upload sebesar 71,22 Mbps. Total hasil download dan hasil upload 68,55+71,22= 139,77 Mbps

\section{c. Total Capacity Download}

Pengujian download mendapatkan hasil sebagai berikut:

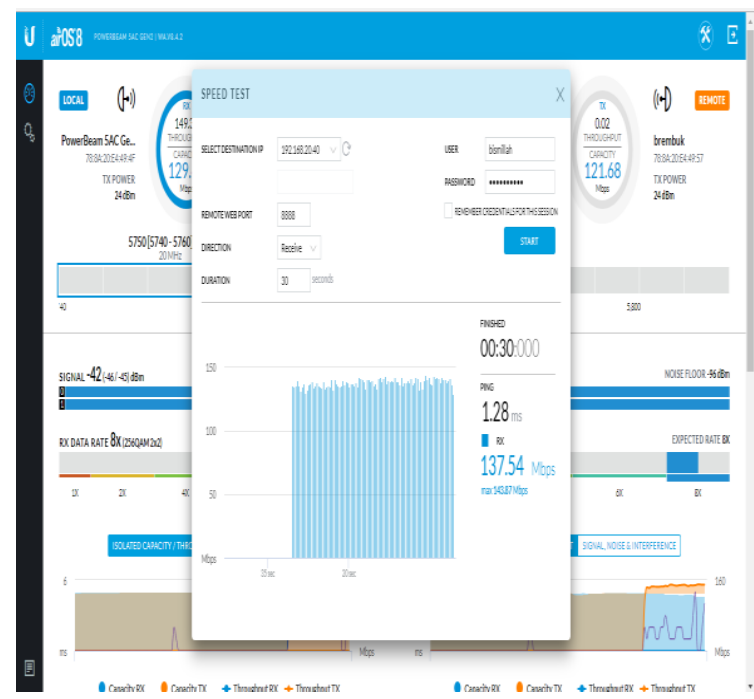

Gambar 4.9. Real Hardware PtP untuk Download 


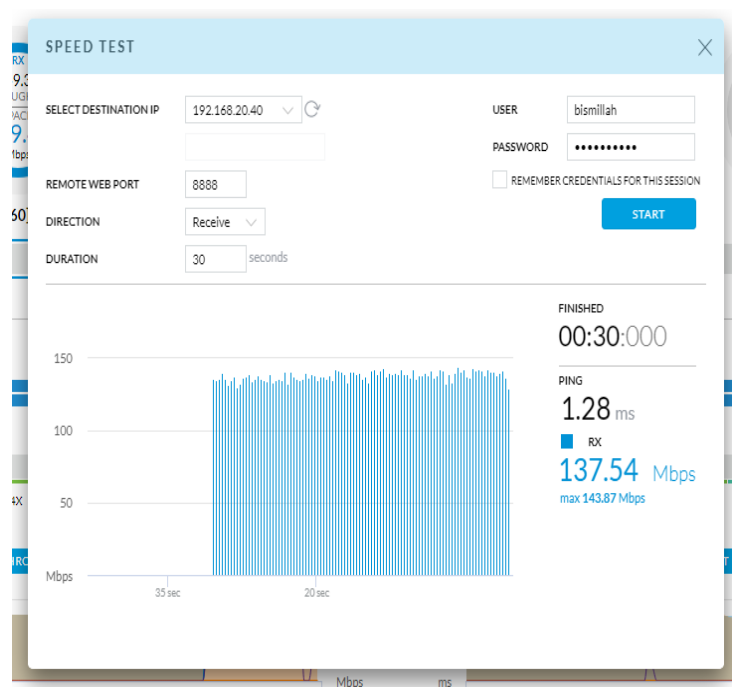

\section{Gambar 4.10. Real Hardware PtP untuk Download}

Gambar 10 dan gambar 11 menunjukan hasil nge-ping dan download dari Access Point ke Station secara bersamaan. Dilakukan dengan 30 kali pengujian dan diperoleh hasil rata-rata ngeping sebesar 1,28 ms, download sebesar 137,54 Mbps.

\section{d. Total Capacity Upload}

Pengujian upload mendapatkan hasil sebagai berikut:

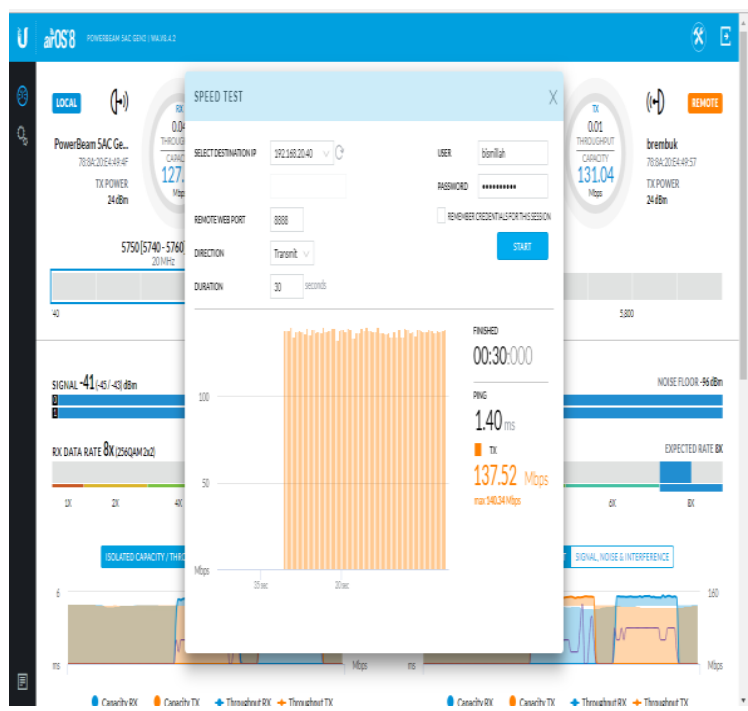

Gambar 4.11. Real Hardware PtP untuk Upload

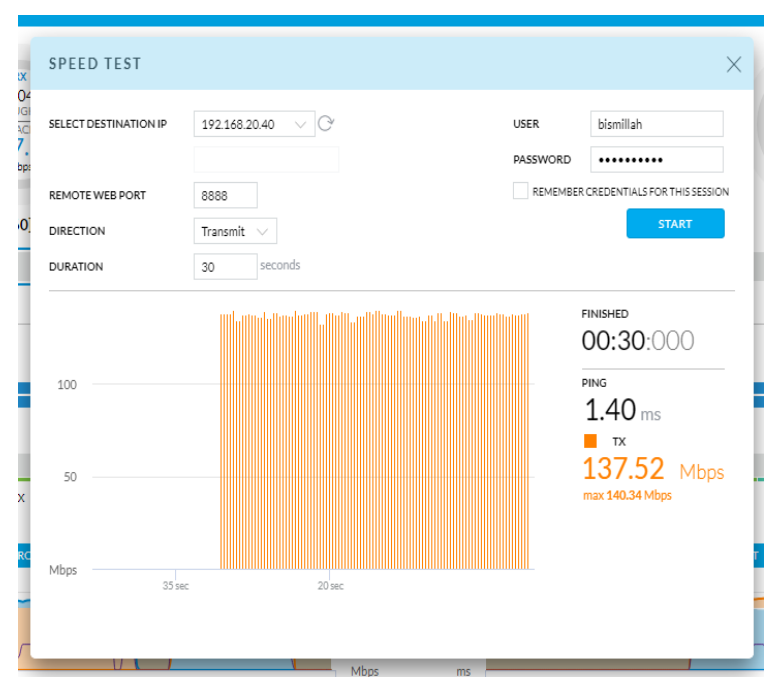

Gambar 4.12. Speed Test PtP untuk Upload

Gambar 12 dan gambar 13 menunjukan hasil nge-ping, download dan upload dari Access Point ke Station secara bersamaan. Dilakukan dengan 30 kali pengujian dan diperoleh hasil rata-rata nge-ping sebesar $1,40 \mathrm{~ms}$, upload sebesar 137,52 Mbps.

e. Frequency

Frequency pada saat instalasi jaringan wireless yang digunakan sebagai berikut:

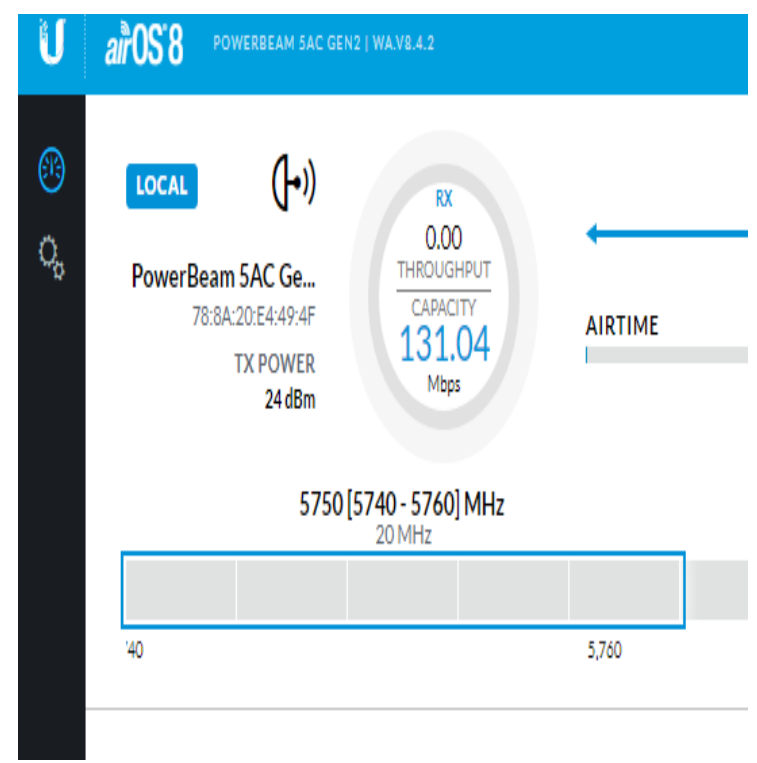

Gambar 4.13. Real Hardware PtP Frequency

Gambar 14 menunjukan frequency yang digunakan 5750 [5740-5760] MHz. 
f. Technology

Technology pada saat instalasi jaringan wireless yang digunakan sebagai berikut:

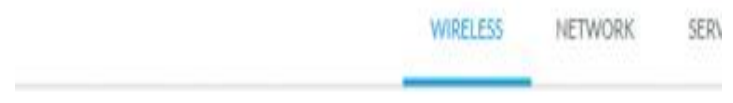

\section{Basic Wireless Settings}

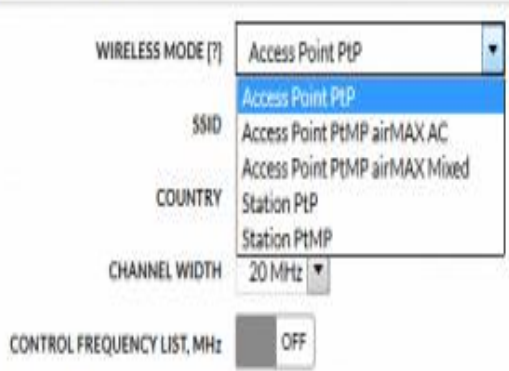

Gambar 4.14. Real Hardware PtP Technology

Gambar 15 menunjukan technology yang digunakan AirMAX AC diambil dari screenshot site A sebagai Access Point.

\section{g. Channel Width}

Channel width pada saat instalasi jaringan wireless yang digunakan sebagai berikut:

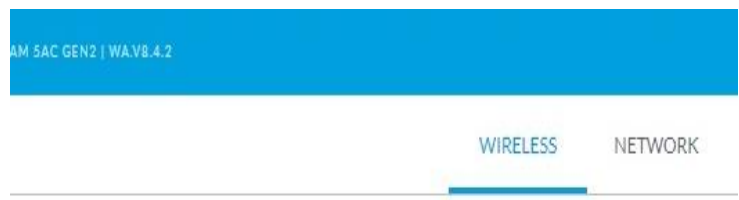

Basic Wireless Settings

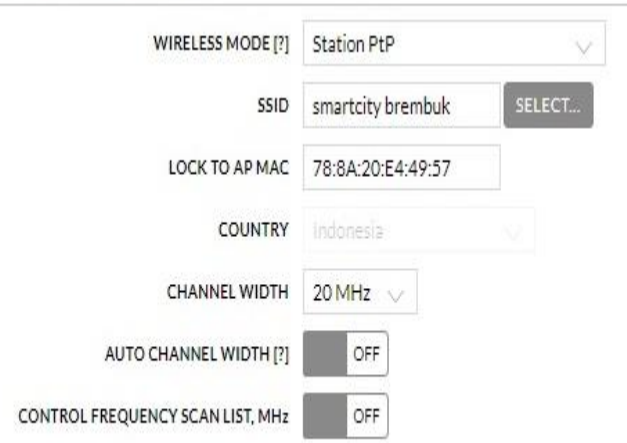

Gambar 4.15. Real Hardware PtP Channel Width

ISSN. 2620-6900 (Online) 2620-6897 (Cetak)
Gambar 15. Menunjukan channel width yang digunakan $20 \mathrm{MHz}$ diambil dari screenshot site B sebagai Station.

4.4 Perbandingan Simulasi Link PtP dan Instalasi PtP Real Hardware

Perbandingan simulasi link PtP dan instalasi link PtP real hardware sebagai berikut:

Tabel 2. Perbandingan Simulasi Link PtP dan Instalasi PtP Real Hardware

\begin{tabular}{|l|l|l|}
\hline Pengujian & $\begin{array}{l}\text { Simulasi PtP } \\
\text { Airlink Ubiquiti }\end{array}$ & $\begin{array}{l}\text { Instalasi PtP } \\
\text { Real } \\
\text { Hardware }\end{array}$ \\
\hline $\begin{array}{l}\text { RX Sinyal } \\
\text { Strength }\end{array}$ & $-37.80 \mathrm{dBm}$ & $-41.00 \mathrm{dBm}$ \\
\hline $\begin{array}{l}\text { Total Capacity } \\
\text { Download \& } \\
\text { Upload }\end{array}$ & $121.10 \mathrm{Mbps}$ & $\begin{array}{l}121.10 \\
\text { Mbps }\end{array}$ \\
\hline Frequency & $5 \mathrm{Ghz}$ & $5 \mathrm{Ghz}$ \\
\hline Tecnology & AirMAX AC & AirMAX AC \\
\hline Channel Width & $20 \mathrm{Mhz}$ & $20 \mathrm{Mhz}$ \\
\hline
\end{tabular}

Dari hasil tabel 2 mMendapatkan perbandingan pada RX sinyal strength simulasi PtP airlink ubiquiti menghasilkan $-37.80 \mathrm{dBm}$, sedangkan pada instalasi PtP real hardware mendapatkan hasil rata-rata $-41.00 \mathrm{dBm}$.

Pada total capacity download \& upload simulasi PtP airlink ubiquiti menghasilkan 121.10 Mbps, sedangkan pada instalasi PtP real hardware mendapatkan hasil rata-rata 137.54 Mbps.

\section{Kesimpulan dan saran}

Kesimpulan dari penelitian ini dari RX sinyal strength pada simulasi lebih bagus dari pada saat menggunakan real hardware karena pada simulasi menghasilkan sinyal $\quad-37.80 \quad \mathrm{dBm}$ sedangkan pada real hardware menghasilkan sinyal $-41.00 \mathrm{dBm}$.

Total capacity download \& upload pada real hardware lebih bagus dari pada saat menggunakan simulasi karena pada real hardware menghasilkan performa $137.54 \mathrm{Mbps}$ sedangkan pada simulasi menghasilkan performa 121.10 Mbps.

Kesimpulan akhir antara penggunaan simulasi ubiquiti airlink.ubnt.com dengan real hardware jaringan produk ubiquiti mendapatkan hasil yang sedikit berbeda dengan kata lain simulasi dan real hardware valid atau hasilnya hampir sama. 
Saran dari penelitian ini adalah penelitian bisa dilanjutkan dengan produk dan lokasi yang berbeda, simulasi airlink.ubnt.com dapat digunakan sebagai acuan simulasi untuk pemilihan hardware produk ubiquiti.

\section{Daftar Pustaka}

[1] Suji., 2013. Transmisi Radio Microwave. Nec Pasolink. PT. Alita Praya Mitra. Jakarta Selatan.

[2] Syafrizal, M. 2005. Pengantar Jaringan Komputer. Penerbit Andi. Yogyakarta

[3] Teare, D. 2008, Designing for Cisco Internetwork Solutions (DESGN), Second Edition. Cisco Press, Cisco System Inc

[4] Anwar, T. 2007. Design And Implementation Of A Wireless Network System In A Smart Campus. CommIT, 127-139.

[5] Duskarnaen, M F., Nurfalah., F. 2017. Analisis, Perancangan, Dan Implementasi Jaringan Wireless Point to Point Antara Kampus A dan Kampus B Universitas Negeri Jakarta. Jurnal Pinter Vol 1 No 2 Desember 2017

[6] Kalaena, L. S., \& Bagye, W. (2018). Implementasi Network Attached Storage (NAS) Menggunakan Freenas Pada STMIK Lombok. Jurnal Manajemen Informatika dan Sistem Informasi, 1(1), 6-10.
[7] Pranoto A., Priadi R A S. 2008. Desain dan Implementasi Wireless LAN Berdasarkan Perhitungan Link Budget DAN Throughput (Studi Kasus BBS UnilaNet - Tiga Satu Mandiri Prima). Electrician Jurnal Rekayasa dan Teknologi Elektro Vol 2 No 2 Mei 2008.

[8] Setyawan, I M G. 2016. Membangun Jaringan Wireless Berbasis Router Mikrotik Dengan Menggunakan Point to Multi Point (PTM) Pada PT. Telkom Pekalongan Provinsi Jawa Tengah. Fakultas Teknologi Dan Informatika Institut Bisnis Dan Informatika, STIKOM Surabaya

[9] Indrajit, R E. 2000. Manajemen Sistem Informasi dan Teknologi Informasi. STIMIK Perbanas Renaissance Center

[10] Mikrotik.co.id Judul artikel "Membangun RT/RW

Net"http://www.mikrotik.co.id/artikel_lihat .php?id=149 di akses pada tanggal 08-09-18 